\title{
PCR Multiplexes Discriminate Fusarium Symbionts of Invasive Euwallacea Ambrosia Beetles that Inflict Damage on Numerous Tree Species Throughout the United States
}

\begin{abstract}
Dylan P. G. Short, Division of Plant and Soil Sciences, West Virginia University, Morgantown; Kerry O'Donnell, Mycotoxin Prevention and Applied Microbiology Research Unit, National Center for Agricultural Utilization Research, United States Department of Agriculture (USDA)Agricultural Research Service, Peoria IL; Jason E. Stajich, Department of Plant Pathology and Microbiology and Institute for Integrative Genome Biology, University of California, Riverside; Jiri Hulcr, School of Forest Resources and Conservation, University of Florida, Gainesville; Teiya Kijimoto, Matthew C. Berger, Angie M. Macias, and Ellie J. Spahr, Division of Plant and Soil Sciences, West Virginia University; Craig C. Bateman, Department of Entomology and Nematology, University of Florida; Akif Eskalen and Shannon C. Lynch, Department of Plant Pathology and Microbiology, University of California; Anthony I. Cognato, Department of Entomology, Michigan State University, East Lansing; Miriam F. Cooperband, Otis Laboratory, USDA Animal and Plant Health Inspection Service-Plant Protection and Quarantine-Center for Plant Health Science and Technology, Buzzards Bay, MA; and Matthew T. Kasson, Division of Plant and Soil Sciences, West Virginia University
\end{abstract}

\begin{abstract}
Asian Euwallacea ambrosia beetles vector Fusarium mutualists. The ambrosial fusaria are all members of the ambrosia Fusarium clade (AFC) within the Fusarium solani species complex (FSSC). Several EuwallaceaFusarium mutualists have been introduced into nonnative regions and have caused varying degrees of damage to orchard, landscape, and forest trees. Knowledge of symbiont fidelity is limited by current identification methods, which typically requires analysis of DNA sequence data from beetles and the symbionts cultured from their oral mycangia. Here, polymerase chain reaction (PCR)-based diagnostic tools were developed to identify the six Fusarium symbionts of exotic Euwallacea spp. currently known within the United States. Whole-genome sequences were generated

for representatives of six AFC species plus $F$. ambrosium and aligned to the annotated genome of $F$. euwallaceae. Taxon-specific primer-annealing sites were identified that rapidly distinguish the AFC species currently within the United States. PCR specificity, reliability, and sensitivity were validated using a panel of 72 Fusarium isolates, including 47 reference cultures. Culture-independent multiplex assays accurately identified two AFC fusaria using DNA isolated from heads of their respective beetle partners. The PCR assays were used to show that Euwallacea validus is exclusively associated with AF-4 throughout its sampled range within eastern North America. The rapid assay supports federal and state agency efforts to monitor spread of these invasive pests and mitigate further introductions.
\end{abstract}

Several destructive fungal plant pathogens vectored by exotic bark and ambrosia beetles (Coleoptera: Curculionidae: Scolytinae) have invaded American landscapes and forests within the past century. For example, the redbay ambrosia beetle Xyleborus glabratus (Eichhoff) and its fungal symbiont Raffaelea lauricola T. C. Harr., Fraedrich $\&$ Aghayeva are responsible for the death of hundreds of millions of native Lauraceous plants, including avocado (Persea americana), redbay (P. borbonia), and sassafras (Sassafras albidum) (Fraedrich et al. 2008; Ploetz et al. 2013) throughout the coastal southeastern United States. Another group of scolytine beetles, the exotic Euwallacea ambrosia beetles, pose a threat to landscape trees as well as avocado (Eskalen et al. 2013; Kasson et al. 2013; Mendel et al. 2012).

At least six Euwallacea spp. from Asia have become established within the United States (Cognato et al. 2015; O'Donnell et al.

Corresponding author: M. T. Kasson; E-mail: mtkasson@mail.wvu.edu

This is scientific article number 3288 of the West Virginia Agricultural and Forestry Experiment Station, Morgantown, WV.

Mention of trade names or commercial products in this publication is solely for the purpose of providing specific information and does not imply recommendation or endorsement by the U.S. Department of Agriculture. USDA is an equal opportunity provider and employer.

*The $\boldsymbol{e}$-Xtra logo stands for "electronic extra" and indicates that three supplementary tables are published online.

Accepted for publication 12 September 2016.

This article is in the public domain and not copyrightable. It may be freely reprinted with customary crediting of the source. The American Phytopathological Society, 2017.
2015): Euwallacea interjectus (Blandford), E. validus (Eichhoff), E. denticulus (Motschulsky), and three morphologically cryptic species within the E. fornicatus species complex (Eichhoff) (Atkinson 2016; O'Donnell et al. 2015; Storer et al. 2015). Euwallacea spp. are fungus-farming ambrosia beetles that cultivate mutualistic fungi in the genus Fusarium, although this is presently unconfirmed for E. denticulus. Most of these insect species do not cause noticeable economic or ecological damage and, instead, attack and colonize declining and recently killed trees. However, some of them are able to colonize living trees, sometimes in massive numbers, and the joint action of the wood borer and their cultivated fungi can cause symptoms known as Fusarium dieback or Fusarium canker. The greatest impact has been reported from the polyphagous shot hole borer on avocado and boxelder in California and Israel, which farms Fusarium euwallaceae S. Freeman, Z. Mendel, T. Aoki \& O'Donnell (Eskalen et al. 2013; Freeman et al. 2013). However, similar testing is needed to confirm pathogenicity and host range of Fusarium stains associated with other introduced Euwallacea spp. in the United States.

The ambrosial fusaria belong to the $F$. solani species complex (FSSC), a clade that includes a number of important canker pathogens of deciduous trees (Park and Juzwik 2012; Tisserat 1987). Molecular systematics has revealed that the FSSC itself comprises three main clades (clades 1 to 3) encompassing over 60 species (O'Donnell et al. 2008; Short et al. 2013; Zhang et al. 2006) and recognizable by genealogical concordance phylogenetic species recognition (Taylor et al. 2000). The ambrosia Fusarium clade (AFC) is a newly discovered lineage within clade 3 of the FSSC. In total, 12 putatively clonal species-level lineages of AFC symbionts have been identified (O'Donnell et al. 2015), 10 of which lack Latin binomials. Therefore, an ad hoc nomenclature (i.e., AF followed by 1 to 12) was developed to distinguish the 12 fusaria within this clade. Most members of the AFC are morphologically indistinguishable (Kasson et al. 2013) and 
produce clavate macroconidia rather than the iconic fusiform conidia characteristic of Fusarium spp. Evolution of clavate macroconidia within this clade has been posited as an adaptation for the symbiosis (Gadd and Loos 1947; Kasson et al. 2013). Some Euwallacea-Fusarium associations appear to be highly specific but parsimony-based cophylogenetic analyses suggest that there have been multiple symbiont shifts over the evolutionary history of this mutualism (O'Donnell et al. 2015).

Despite the genealogical exclusivity of Fusarium symbionts and the successful delimitation of several AFC species using arbitrary-primer polymerase chain reaction (PCR) (Freeman et al. 2013), rapid detection and discrimination of Fusarium symbionts remains challenging for several reasons: (i) at least one Euwallacea sp. present within the United States and one in Sri Lanka farm two closely related ambrosia fusaria (O'Donnell et al. 2015); (ii) preliminary evidence suggests that interspecific hybridization may occur between members of the AFC and possibly with FSSC members outside the AFC, which presents challenges in resolving species boundaries; (iii) identification of species within the FSSC generally necessitates DNA sequence analysis of phylogenetically informative loci; and (iv) the current reliance on culturing and isolation of the symbionts requires living beetles, which precludes analysis of ethanol-preserved specimens.

Surveillance programs focused on the detection of beetles (genus Euwallacea) and disease (Fusarium dieback) have been initiated in several states and on the federal level within the United States Department of Agriculture program Cooperative Agricultural Pest Surveys. However, given the morphological uniformity of many species within the AFC (Kasson et al. 2013; O'Donnell et al. 2015), reliable molecular tools to discriminate exotic Fusarium symbionts are needed in order to advance our understanding of their ecology, distribution, and global invasion dynamics.

The present study was initiated to (i) develop and validate diagnostically robust multiplex assays to discriminate Fusarium symbionts of exotic Euwallacea ambrosia beetles currently present within the United States and (ii) validate multiplex assays that accurately identify AFC fusaria from DNA extracts of freshly macerated heads from living beetles. To bypass the need for fungal culturing, which often requires freshly collected live or recently killed beetles, we tested whether the multiplex PCR assays could be used to amplify DNA extracted directly from beetle heads. Amplification of fusarial DNA directly from beetle heads would facilitate research and detection of these fungi through a rapid culture-independent assessment and through simultaneous detection of different Fusarium spp. cooccurring in the same mycangium.

\section{Materials and Methods}

AFC comparative genomics. All of the AFC fusaria were originally isolated from live ambrosia beetles or their active galleries (Supplementary Table S1). Cultures were maintained on potato dextrose agar (Beckton, Dickinson and Company, Franklin Lakes, $\mathrm{NJ}$ ) and transferred to potato dextrose broth to obtain mycelium for DNA extraction. A hexadecyltrimethyl-ammonium bromide (SigmaAldrich, St. Louis) protocol was used to obtain total genomic DNA for Sanger sequencing on an ABI3730 and for the multiplex assays (O'Donnell et al. 1998). Total genomic DNA for whole-genome sequencing was obtained using a ZR Fungal/bacterial DNA MiniPrep kit (Zymo Research, Irvine, CA). Whole-genome sequences of the following seven AFC species were generated with the Illumina MiSeq platform using libraries prepared with the NexteraXT kit following the manufacturer's instructions (Illumina, San Diego, CA): NRRL 20438 F. ambrosium (AF-1) from tea (Camelia chinensis) in India; NRRL 62626 F. euwallaceae (AF-2) from avocado in Los Angeles, CA; NRRL 62606 (AF-3) Fusarium sp. from boxelder (Acer negundo) in Gainesville, FL; NRRL 62579 Fusarium sp. (AF-4) from Ailanthus altissima in Pennsylvania; NRRL 62590 Fusarium sp. (AF-6) from avocado in Miami-Dade County, FL; NRRL 62584 Fusarium sp. (AF-8) from avocado in Miami-Dade County, FL; and KOD 792 Fusarium sp. (AF-12) from California sycamore (Platanus racemosa) in San Diego County, CA.
Sequence reads of the AFC genomes were trimmed and assembled with applications in CLC Genomics Workbench (Qiagen Bioinformatics, Redwood City, CA). The reads were assembled into 3,362 contigs. The assembly L50 was $68.1 \mathrm{~kb}$, with the longest contig $312 \mathrm{~kb}$ in length. Genome annotation was performed using MAKER (Campbell et al. 2014), which takes in ab initio predictions from SNAP (Korf 2004), Augustus (Stanke et al. 2006), and GeneMark-ES (Borodovsky and Lomsadze 2011; Ter-Hovhannisyan et al. 2008). SNAP and Augustus ab initio parameters were initially run with $F$. graminearum parameters (https://github.com/hyphaltip/ fungi-gene-prediction-params) followed by parameter training on high-quality predictions from MAKER determined by transcript and protein support (AED better than 0.1). Repetitive elements were first identified by de novo repeat element discovery by RepeatModeler Open-1.0.7 (http://www.repeatmasker.org/RepeatModeler.html, Institute for Systems Biology, Seattle) followed by genome masking with RepeatMasker Open 3.0 (http://www.repeatmasker.org/faq. html, Institute for Systems Biology, Seattle, WA). RNAseq data were used in the genome annotation (Elmore et al. 2015), which was first assembled into transcripts with Trinity (Grabherr et al. 2011; Haas et al. 2013) using the Genome-Guided mode. Transcripts were aligned to the genome with BLASTN followed by exonerate polishing of alignments to obtain accurate intron/exon splice sites (Slater and Birney 2005) within MAKER. Proteins from annotated Sordariomycete genomes from the Swissprot database were clustered with cd-hit (Fu et al.2012) at $80 \%$ and aligned to the genome with TBLASTN followed by exonerate splice-site polishing in MAKER. Gene calls resulted in 17,438 predicted protein-coding genes. Raw Illumina reads from the remaining genomes were converted to FASTQsanger using Galaxy tools (https://usegalaxy.org/) and mapped to the $F$. euwallaceae genome using CLC Genomics Workbench (Qiagen Bioinformatics). A track list was created in CLC Genomics containing all seven genomes and predicted gene annotations. Contigs were searched manually for potential primer binding sites that would selectively anneal to DNA from each target species, due to unique nucleotide polymorphisms and insertion/ deletions (Fig. 1), and yielded an amplicon between 200 and $2,000 \mathrm{bp}$.

Fusarium spp.-specific oligonucleotide primer development and PCR multiplexing. In all, 3 to 15 different primer pairs per Fusarium sp. were tested for specificity against a panel that included all 12 AFC species but only 1 primer pair per species was selected due to nontarget amplifications in the other primer sets (Integrated DNA Technologies, Coralville, Iowa). Potential species-specific primers were tested in PCR using DNA from two representatives each of AF-1 through AF-12, except for AF-5 and AF-10, where only one reference strain was available (Table 1). Primers were also tested using DNA from three AFC strains previously identified as putative interspecific hybrids (Kasson et al. 2013). All PCR were performed in $25.5-\mu 1$ reactions containing $12.5 \mu \mathrm{l}$ of Bioline HS $2 \times$ PCR Mix (Bioline USA Inc., Taunton, MA), $10 \mu \mathrm{l}$ of sterile distilled water, $1 \mu$ l each of $10 \mathrm{nM}$ oligonucleotide primer, and $1 \mu$ l of genomic DNA (gDNA). Optimal annealing temperatures were determined on a gradient from 57 to $67^{\circ} \mathrm{C}$ across all primer sets (data not shown). All reactions were carried out in an MJ Research thermocycler with the following conditions: $95^{\circ} \mathrm{C}$ for $2 \mathrm{~min}$, followed by 34 cycles of $95^{\circ} \mathrm{C}$ for $30 \mathrm{~s}$, the optimal annealing temperature (Table 1) for $30 \mathrm{~s}$, and $72^{\circ} \mathrm{C}$ for 60 to $90 \mathrm{~s}$, depending on expected target length (Table 1). PCR products $(10 \mu \mathrm{l}$ each) were visualized on $1.5 \%(\mathrm{wt} / \mathrm{vol})$ agarose gels with $4 \mu \mathrm{l}$ of $1 \times$ SYBR Gold (Invitrogen, Grand Island, NY) and $4 \mu \mathrm{l}$ of $1 \times$ gel loading dye (5Prime, Gaithersburg, MD) in $0.5 \%$ Tris-borate-EDTA buffer (Amresco, Solon, $\mathrm{OH}$ ). Gels were run at 80 to $90 \mathrm{~V}$ for 1.5 to $2 \mathrm{~h}$ before visualizing on a UV transilluminator (Syngene, Frederick, MD). Amplicons were sized using 100-bp and 1-kb molecular weight ladders (Omega Bio-tek, Norcross, GA).

Primer pairs were considered species-specific if amplicons were only produced for a given target species. To confirm that the expected region had been amplified, amplicons were purified using EXOSAP-IT (Affymetrix, Santa Clara, CA) and sequenced using 
the same forward and reverse primers used in PCR (Eurofins Operon, Huntsville, AL). After the six primer pairs were designed and tested, three multiplex assays were developed that combined primers specific to the following three pairs of AFC species based on their geographic proximity: F. euwallaceae (AF-2) and $\mathrm{AF}-12$ in southern
California, AF-3 and AF-4 in the eastern United States, and AF-6 and AF-8 in Miami-Dade County, FL. To assess whether the assays could coamplify the target loci from each pair of AFC species, a 1:1 mixture of template DNA from each pair was included in each assay.

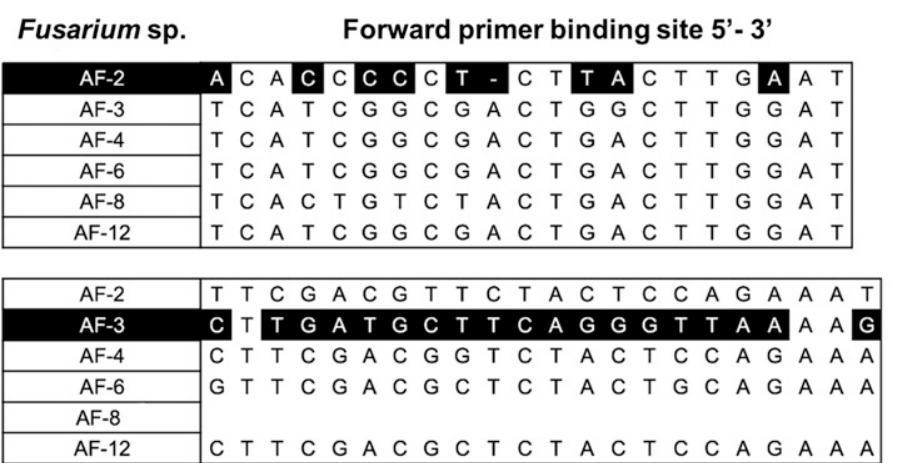

\begin{tabular}{|c|c|c|c|c|c|c|c|c|c|c|c|c|c|c|c|c|c|c|c|c|c|c|}
\hline AF-2 & C & & - & - & $\mathrm{C}$ & $T$ & & G & C & $T$ & - & & C & $A$ & $\mathrm{~T}$ & $\mathrm{~T}$ & G & $A$ & & G & & $-G$ \\
\hline AF-3 & C & - & - & - & C & $T$ & A & G & C & A & - & - & C & A & $\mathrm{T}$ & $\mathrm{T}$ & G & A & & C & 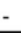 & \\
\hline AF -4 & & A & A & r & C & $\mathrm{T}$ & A & G & G & $T$ & A & & $T$ & $\mathbf{T}$ & G & 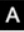 & C & G & $\mathrm{T}$ & A & 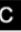 & \\
\hline AF-6 & $C$ & - & - & - & C & $\mathrm{T}$ & - & G & G & C & A & - & - & C & A & $\mathrm{T}$ & $T$ & G & & C & & $-G$ \\
\hline AF-8 & C & $\mathrm{T}$ & G & C & $\mathrm{T}$ & $\mathrm{T}$ & $T$ & C & $T$ & A & G & C & C & $T$ & $\mathrm{~T}$ & G & A & - & C & - & - & \\
\hline AF-12 & C & - & - & - & C & $\mathrm{T}$ & G & G & C & $\mathrm{T}$ & - & - & C & A & $T$ & $T$ & G & A & & G & - & \\
\hline
\end{tabular}

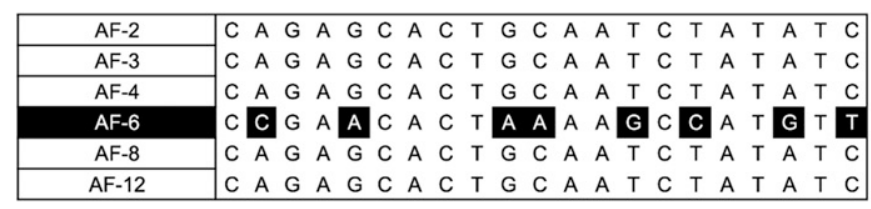

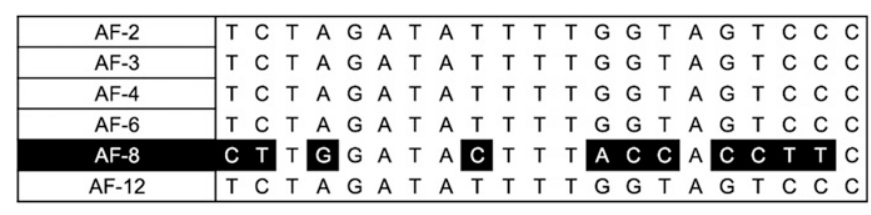

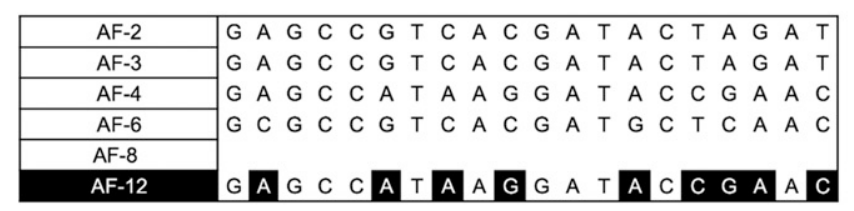

Reverse primer binding site 3'- 5'

\begin{tabular}{|llllllllllllllllllllllll|}
\hline$A$ & $G$ & $A$ & $A$ & $T$ & $A$ & $A$ & $C$ & $A$ & $A$ & $T$ & $G$ & $C$ & $A$ & $A$ & $G$ & $C$ & $G$ & $T$ & $C$ & $T$ \\
$A$ & $G$ & $A$ & $T$ & $C$ & $A$ & $T$ & $G$ & $A$ & $A$ & $T$ & $C$ & $C$ & $G$ & $A$ & $A$ & $C$ & $T$ & $T$ & $C$ & $C$ \\
$A$ & $G$ & $A$ & $T$ & $C$ & $A$ & $T$ & $G$ & $A$ & $A$ & $C$ & $C$ & $C$ & $G$ & $A$ & $A$ & $C$ & $T$ & $T$ & $C$ & $C$ \\
$A$ & $G$ & $A$ & $R$ & $C$ & $A$ & $T$ & $G$ & $A$ & $A$ & $T$ & $C$ & $C$ & $G$ & $A$ & $A$ & $C$ & $T$ & $T$ & $C$ & $C$ \\
$A$ & $G$ & $T$ & $A$ & $T$ & $A$ & $T$ & $G$ & $A$ & $A$ & $C$ & $C$ & $T$ & $G$ & $A$ & $G$ & $C$ & $T$ & $T$ & $C$ & $C$ \\
$A$ & $G$ & $A$ & $T$ & $C$ & $A$ & $T$ & $G$ & $A$ & $A$ & $C$ & $C$ & $C$ & $G$ & $A$ & $A$ & $C$ & $T$ & $T$ & $C$ & $C$ \\
\hline
\end{tabular}

\begin{tabular}{|lllllllllllllllllllll|}
\hline$G$ & $T$ & $T$ & $T$ & $G$ & $A$ & $C$ & $C$ & $C$ & $T$ & $G$ & $A$ & $C$ & $A$ & $T$ & $G$ & $A$ & $A$ & $G$ & $T$ & $C$ \\
$A$ & $T$ & $T$ & $T$ & $G$ & $G$ & $T$ & $C$ & $C$ & $T$ & $G$ & $A$ & $C$ & $A$ & $T$ & $C$ & $A$ & $A$ & $G$ & $T$ & $T$ \\
\hline$G$ & $T$ & $T$ & $T$ & $G$ & $G$ & $C$ & $C$ & $C$ & $T$ & $G$ & $A$ & $C$ & $A$ & $A$ & $A$ & $G$ & $A$ & $G$ & $C$ & $C$ \\
$A$ & $T$ & $T$ & $T$ & $A$ & $A$ & $C$ & $C$ & $C$ & $T$ & $G$ & $A$ & $C$ & $A$ & $T$ & $G$ & $A$ & $A$ & $G$ & $T$ & $C$ \\
$A$ & $T$ & $C$ & $C$ & $G$ & $G$ & $C$ & $C$ & $C$ & $T$ & $G$ & $A$ & $T$ & $A$ & $T$ & $G$ & $A$ & $A$ & $G$ & $T$ & $C$ \\
$G$ & $T$ & $T$ & $T$ & $G$ & $A$ & $C$ & $C$ & $C$ & $T$ & $G$ & $A$ & $C$ & $A$ & $T$ & $G$ & $A$ & $A$ & $G$ & $T$ & $C$ \\
\hline
\end{tabular}

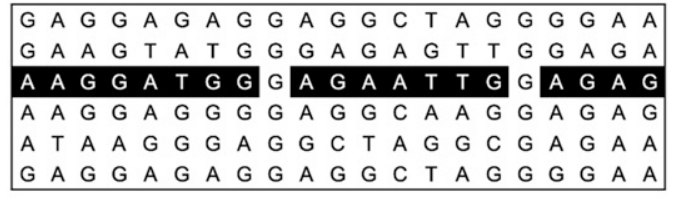

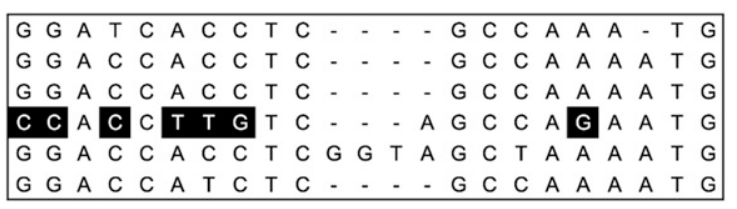

\begin{tabular}{lllllllllllllllllllll}
\hline$G$ & $C$ & $T$ & $G$ & $G$ & $A$ & $A$ & $G$ & $A$ & $T$ & $T$ & $T$ & $T$ & $A$ & $C$ & $C$ & $A$ & $T$ & $G$ & $T$
\end{tabular} G C T G G A A G A T T T T A C C A T G T G C T G G A A G A T T T T A C C A T G T

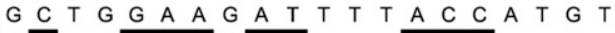
G T T G T G G G C A T T T T G T G A $T$ T C T $\begin{array}{llllllllllllllllllll}G & C & T & G & G & A & A & G & A & T & T & T & T & A & C & C & A & T & G & T\end{array}$

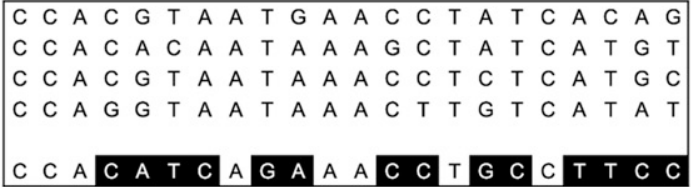

Fig. 1. Sequence alignments of genomic regions containing binding sites of ambrosia Fusarium clade species-specific oligonucleotide primers. Black fill indicates target species and nucleotide polymorphisms within primer binding sites. Blank sequence indicates no genomic coverage available.

Table 1. Primer sequences for taxon-specific marker loci used to distinguish six ambrosia Fusarium clade (AFC) species ${ }^{\mathrm{a}}$

\begin{tabular}{|c|c|c|c|c|c|c|c|}
\hline Target & Forward primer $5^{\prime}-3^{\prime}$ & Reverse primer $5^{\prime}-\mathbf{3}^{\prime}$ & $\operatorname{Amp}(\mathbf{b p})$ & $\mathbf{T}\left({ }^{\circ} \mathbf{C}\right)$ & $\begin{array}{c}\text { Ext } \\
(\mathbf{m i n})\end{array}$ & GenBank & $\begin{array}{l}\text { BLASTp search } \\
\text { results }\end{array}$ \\
\hline $\mathrm{AF}-2$ & ACACCСССТCTTACTTGAAT & AGACGCTTGCATTGTTATTCT & 260 & 62 & 1:00 & KT835019 & $\begin{array}{l}\text { Fungal transcription factor } \\
\text { regulatory middle } \\
\text { homology region }\end{array}$ \\
\hline AF-3 & CTTGATGCTTCAGGGTTAAAAG & AACTTGATGTCAGGACCAAAT & 1,370 & 64 & $1: 10$ & KT835020 & $\begin{array}{l}\text { Rossmann-fold NAD }(\mathrm{P})(+)- \\
\text { binding proteins }\end{array}$ \\
\hline $\mathrm{AF}-4$ & CAAACTAGGTACTTGACGTACTG & СТСТССААТТСТСССАТССТТ & 751 & 64 & $1: 10$ & KT835021 & $\begin{array}{l}\text { Adenylate forming domain, } \\
\text { Class I superfamily } \\
\text { bifunctional fatty acid } \\
\text { transporter/very-long- } \\
\text { chain acyl-CoA } \\
\text { synthetase }\end{array}$ \\
\hline AF-6 & CCGAACACTAAAAGCCATGTT & CATTCTGGCTGACAAGGTGG & 1,202 & 65 & $1: 30$ & KT835022 & $\begin{array}{l}\text { No putative conserved } \\
\text { domains detected }\end{array}$ \\
\hline AF-8 & CTTGGATACTTTACCACCTTC & AGATCACAAATGCCCACAAC & 621 & 65 & $1: 30$ & KT835023 & $\begin{array}{l}\text { Uncharacterized conserved } \\
\text { protein (DUF2196) }\end{array}$ \\
\hline AF-12 & GAGCCATAAGGATACCGAAC & GGAAGGCAGGTTTCTGATGTGG & 1,243 & 62 & 1:00 & KT835024 & $\begin{array}{l}\text { No putative conserved } \\
\text { domains detected }\end{array}$ \\
\hline
\end{tabular}

$\overline{\mathrm{a}}$ Target $=$ target Fusarium spp., Amp $=$ expected amplicon size, $\mathrm{T}=$ annealing temperature, Ext $=$ extension time, and GenBank $=$ GenBank accession numbers. 
Primer validation and conservation of primer binding sites. In addition to the fusaria mentioned above, DNA from nine clade 3 FSSC species related to the AFC were included in the test of specificity of the six primer pairs (Table 2). This panel contained two representatives of phylospecies FSSC 6, 8, and 10, which are the closest relatives of the AFC (Table 2) (O'Donnell et al. 2008). Of the 18 non-AFC FSSC strains chosen for validation, 10 were fusaria recovered from several bark beetle species (i.e., FSSC 13, 14, 18, 25 , and 29).

To further confirm the utility of primer binding sites, 25 additional AF-4 strains were obtained from mature E. validus collected in 2014 to 2015 from multiple locations in the United States (Supplementary Table S2). E. validus was chosen primarily because of its longer residency (Wood 1982) compared with other Euwallacea spp. currently established in the United States and its wide distribution throughout the eastern United States (Cognato et al. 2015). Samples were collected as far south as Clarkesville, GA (Rabun County) and as far north as Huntingdon, PA (Huntingdon County, PA). DNA was extracted from Fusarium cultures derived from single conidia, as previously described (Kasson et al. 2013). Templates were used in PCR containing two primer pairs in the following combinations: primers specific to AF-3/AF-4, AF-6/AF-8, and AF-2/AF-12. In addition to testing whether primer binding sites were conserved in Fusarium symbionts in E. validus throughout the beetle's invaded range in the United States, multiplexing also permitted testing hypotheses regarding symbiont cocultivation and symbiont switching, both of which have been documented in Euwallacea spp. (O'Donnell et al. 2015). This was especially relevant given that $E$. interjectus overlaps with E. validus at the southernmost extent of the latter species' known range, and the two species vector different AFC species.

Sensitivity. The sensitivity of simplex PCR and the three multiplexes was tested using DNA extracted from pure cultures. For simplexes (individual-species PCR), two reference isolates from each of the six target AFC species were used (Table 3). Genomic DNA was diluted to the following concentrations: $100,50,25,10$, and $1 \mathrm{ng} / \mu \mathrm{l}$ and 100,10 , and $1 \mathrm{pg} / \mu \mathrm{l}$. Concentrations were verified using a NanoDrop spectrophotometer (NanoDrop Products, Wilmington, DE). PCR assays were performed in duplicate using $1 \mu \mathrm{l}$ of gDNA template per reaction. To test the sensitivity of multiplexes, the dilutions of 100,25 , and $1 \mathrm{ng} / \mu \mathrm{l}$ were used in mixed template reactions, which utilized $1 \mu \mathrm{l}$ of gDNA from each isolate of the two different AFC species.

Amplification of fusarial DNA directly from mature beetle heads. E. validus heads that were removed from preemergence, mature females in tree-of-heaven (A. altissima) stems in West Virginia and mature E. interjectus from infested boxelder in Florida were placed individually or in groups of 2, 5, 10, or 20 in 1.5-ml Eppendorf tubes. Whole DNA was assayed using each of the three multiplex PCR. Samples containing two or more heads permitted simultaneous processing of multiple individuals from the same colony to determine what AFC species they vectored. DNA was extracted as previously described (Short et al. 2015).

\section{Results}

Primer validation and PCR multiplexing. All six primer pairs proved to be species specific and capable of distinguishing ambrosial fusaria AF-2, AF-3, AF-4, AF-6, AF-8, and AF-12 (Table 2). Amplicons of the expected size were produced for the two target species in each of the three multiplex assays, and not for the six other AFC species or the nine closely related FSSC clade 3 species (Table 2; Fig. 2). Amplicon sizes were as follows: AF-3 and AF-4: 1,370 and $751 \mathrm{bp}$, AF-6 and AF-8: 1,202 and $621 \mathrm{bp}$, and AF-2 and AF-12: 260 and 1,243 bp. PCR of the putative triparental interspecific hybrid NRRL 62605 F. ambrosium (AF-1) from Sri Lanka produced a positive genotype using the AF-3 primer pair. The sequence from the putative hybrid, which was identified as a NAD(P)-binding Rossmann fold domain-specific protein, was $100 \%$ identical to the amplicon obtained from NRRL 62606 (AF-3) Fusarium sp. from Gainesville, FL (Table 1). BLASTp search results of protein sequences revealed that all but two translated sequences (AF-6 and AF-12 species-specific marker loci) contained conserved protein domains (Table 2).

Sensitivity. All six primer pairs were able to amplify their respective target of the gDNA template at or below $1 \mathrm{ng} / \mu \mathrm{l}$ (Table 3 ). The primer pairs for two AF-4, one AF-6, and two AF-8 isolates showed sensitivity several orders of magnitude below $1 \mathrm{ng} / \mu \mathrm{l}$, with positive detection at or below $10 \mathrm{pg} / \mu \mathrm{l}$ (Table 3). Multiplex PCR using mixed template gDNA resulted in successful coamplification for seven of nine combinations at $100 \mathrm{ng} / \mu \mathrm{l}, 8$ of 11 combinations at $25 \mathrm{ng} / \mu \mathrm{l}$, and 5 of 11 at $1 \mathrm{ng} / \mu \mathrm{l}$ (Fig. 3; Supplementary Table S3). At least one of the two PCR products amplified in all reactions. A majority of the multiplexes that failed involved mixed templates of AF-3 and AF-4. The remaining coamplifications that failed were at the $1 \mathrm{ng} / \mu \mathrm{l}$ concentration and included at least one mixed template of AF-2 and AF-12, AF-6 and AF-8, and AF-3 and AF-4.

Amplification of fusarial DNA directly from beetle heads. The AF-3/AF-4, AF-2/AF-12, and AF-6/AF-8 PCR multiplexes were tested on DNA templates extracted from 1, 2, 5, 10, and 20 heads of freshly caught $E$. validus and $E$. interjectus from the eastern United States. The AF-3/AF-4 multiplex yielded amplicons of the expected size for both species in all batched samples (i.e., 2 to 20 heads) but amplicons were not obtained from individual heads. The AF-3specific target was amplified from all E. interjectus and an AF-4specific target was amplified from all E. validus (Table 2), which demonstrates both the specificity of our assay as well as the specificity of these particular beetle-fungus associations within the United States. As expected, AF-2/AF-12 and AF-6/AF-8 multiplexes yielded no amplicons from any of the E. validus or E. interjectus DNA extractions.

\section{Discussion}

In this study, we validated a rapid diagnostic tool for characterizing fusarial symbionts of Euwallacea ambrosia beetles present in the United States. Primer specificity and reliability were confirmed through a screen of a phylogenetically diverse set of AFC strains as well as representatives of nine closely related species within clade 3 of the FSSC $(n=72)$. PCR were further validated on whole DNA extracted from macerated beetle heads containing conidia. For both fungal and whole-beetle DNA, all primer annealing sites appeared to be species specific and conserved intraspecifically and even added support for a tripartite hybrid origin of NRRL 62605 F. ambrosium (Kasson et al. 2013).

Other methods for identifying Fusarium symbionts cultivated by Euwallacea spp. have relied on analysis of DNA sequence data from phylogenetically informative loci (O'Donnell et al. 2015). A recent method using arbitrarily primed (ap)-PCR was able to discern F. euwallaceae from several strains of AF-1 and AF-4 (Freeman et al. 2013). ap-PCR is inexpensive and convenient, in that it only requires three universal primers with no additional genomic data. However, without testing additional isolates representing the remaining nine AFC species and other FSSC, it remains unclear whether ap-PCR could resolve all of the AFC species. Taxon-specific PCR assays such as the one developed here are reliable and easily interpreted, and have been developed in several important pathosystems (Dreaden et al. 2014; Inderbitzin et al. 2013).

The newly designed primer sets amplify their correct targets in concentrations at or below $1 \mathrm{ng} / \mu \mathrm{l}$ for all gDNA templates, and at or below $10 \mathrm{pg} / \mu \mathrm{l}$ for three AFC species, which is comparable with previously reported sensitivity for multiplex assays of phytopathogenic fungi (Dreaden et al. 2012; Rigotti et al. 2002) and bacteria (Balestra et al. 2013). The multiplex assays successfully identified AF-3 and AF-4 from pooled DNA from eight batches of freshly macerated E. interjectus and E. validus beetle heads, respectively. These results, coupled with the sensitivity assays, may indicate that singleton beetles contained fungal gDNA below detectable limits. However, more work is needed to confirm the concentration of gDNA from the mycangia of Euwallacea ambrosia beetles. Follow-up studies comparing whole-DNA extraction methods from freshly collected and ethanol-preserved beetle specimens are needed to 
Table 2. Strain and beetle identification (ID) and results of polymerase chain reaction (PCR) and sequencing experiments

\begin{tabular}{|c|c|c|c|c|c|c|c|c|c|}
\hline \multirow[b]{2}{*}{ Fusarium spp. ${ }^{\mathbf{a}}$} & \multirow[b]{2}{*}{ ID $^{\mathbf{b}}$} & \multicolumn{6}{|c|}{ Tested via multiplex PCR } & \multicolumn{2}{|c|}{ Sequence confirmed } \\
\hline & & AF-2 & AF-3 & AF-4 & AF-6 & AF-8 & AF-12 & $E F 1-\alpha$ & $\mathrm{AFC}^{\mathrm{c}}$ \\
\hline AF-1 Fusarium ambrosium & NRRL 20438 & - & - & - & - & - & - & + & $\ldots$ \\
\hline AF-1 F. ambrosium & NRRL 62942 & - & - & - & - & - & - & + & $\ldots$ \\
\hline AF-2 F. euwallaceae & NRRL 54727 & - & - & - & - & - & - & + & + \\
\hline AF-2 F. euwallaceae & NRRL $62626^{\mathrm{d}}$ & + & - & - & - & - & - & + & $\ldots$ \\
\hline AF-3 Fusarium sp. & NRRL 62629 & - & + & - & - & - & - & + & + \\
\hline AF-3 Fusarium sp. & NRRL $62606^{d}$ & - & + & - & - & - & - & + & + \\
\hline AF-3 Fusarium sp. & $\mathrm{EiF} 20^{\mathrm{e}}$ & - & + & - & - & - & - & $\ldots$ & + \\
\hline AF-3 Fusarium sp. & EiF10 & - & + & - & - & - & - & $\ldots$ & + \\
\hline AF-3 Fusarium sp. & $\mathrm{EiF}^{\mathrm{e}}$ & - & + & - & - & - & - & $\ldots$ & $\ldots$ \\
\hline AF-3 Fusarium sp. & $\mathrm{EiF}^{\mathrm{e}}$ & - & + & - & - & - & - & $\ldots$ & $\ldots$ \\
\hline AF-3 Fusarium sp. & $\mathrm{EiF} 1^{\mathrm{e}}$ & - & - & - & - & - & - & $\ldots$ & $\ldots$ \\
\hline AF-4 Fusarium sp. & NRRL $62579^{\mathrm{d}}$ & - & - & + & - & - & - & + & + \\
\hline AF-4 Fusarium sp. & NRRL 62578 & - & - & + & - & - & - & + & $\ldots$ \\
\hline AF-4 Fusarium sp. & NRRL 62582 & - & - & + & - & - & - & + & $\ldots$ \\
\hline AF-4 Fusarium sp. & EvF20e & - & - & + & - & - & - & $\ldots$ & + \\
\hline AF-4 Fusarium sp. & EvF10 & - & - & + & - & - & - & $\cdots$ & + \\
\hline AF-4 Fusarium sp. & $\mathrm{EvF}^{\mathrm{e}}$ & - & - & + & - & - & - & $\ldots$ & $\ldots$ \\
\hline AF-4 Fusarium sp. & $\mathrm{EvF} 2^{\mathrm{e}}$ & - & - & + & - & - & - & $\cdots$ & $\cdots$ \\
\hline AF-4 Fusarium sp. & $\mathrm{EvF} 1^{\mathrm{e}}$ & - & - & - & - & - & - & $\cdots$ & $\ldots$ \\
\hline AF-5 Fusarium sp. & NRRL 22231 & - & - & - & - & - & - & + & $\ldots$ \\
\hline AF-6 Fusarium sp. & NRRL 62591 & - & - & - & + & - & - & + & $\ldots$ \\
\hline AF-6 Fusarium sp. & NRRL $62590^{\mathrm{d}}$ & - & - & - & + & - & - & + & + \\
\hline AF-6 Fusarium sp. & KOD 133 & - & - & - & + & - & - & + & $\ldots$ \\
\hline AF-6 Fusarium sp. & KOD 134 & - & - & - & + & - & - & + & $\ldots$ \\
\hline AF-7 Fusarium sp. & NRRL 62610 & - & - & - & - & - & - & + & $\ldots$ \\
\hline AF-7 Fusarium sp. & NRRL 62611 & - & - & - & - & - & - & + & $\ldots$ \\
\hline AF-8 Fusarium sp. & NRRL 62585 & - & - & - & - & + & - & + & + \\
\hline AF-8 Fusarium sp. & NRRL $62584^{\mathrm{d}}$ & - & - & - & - & + & - & + & $\ldots$ \\
\hline AF-9 Fusarium sp. & NRRL 22643 & - & - & - & - & - & - & + & $\ldots$ \\
\hline AF-9 Fusarium sp. & NRRL 66088 & - & - & - & - & - & - & + & $\cdots$ \\
\hline AF-10 Fusarium sp. & NRRL 62941 & - & - & - & - & - & - & + & $\ldots$ \\
\hline AF-11 Fusarium sp. & NRRL 62944 & - & - & - & - & - & - & + & $\ldots$ \\
\hline AF-11 Fusarium sp. & NRRL 62943 & - & - & - & - & - & - & + & $\ldots$ \\
\hline AF-12 Fusarium sp. & NRRL 62945 & - & - & - & - & - & + & + & + \\
\hline AF-12 Fusarium sp. & KOD $792^{d}$ & - & - & - & - & - & + & + & $\ldots$ \\
\hline AF-12 Fusarium sp. & NRRL 62946 & - & - & - & - & - & + & + & $\cdots$ \\
\hline AF-1 F. ambrosium (hybrid) & NRRL 46583 & - & - & - & - & - & - & + & $\ldots$ \\
\hline AF-1 F. ambrosium (hybrid) & NRRL 22345 & - & - & - & - & - & - & + & $\ldots$ \\
\hline AF-1 F. ambrosium (hybrid) & NRRL 62605 & - & + & - & - & - & - & + & $+(\mathrm{AF}-3)$ \\
\hline FSSC 6-p & KOD 327 & - & - & - & - & - & - & + & $\ldots$ \\
\hline FSSC 6-s & KOD 330 & - & - & - & - & - & - & + & $\ldots$ \\
\hline FSSC 8-a (F. neocosmosporiellum) & NRRL 43467 & - & - & - & - & - & - & + & $\cdots$ \\
\hline FSSC 8-b & NRRL 22436 & - & - & - & - & - & - & + & $\ldots$ \\
\hline FSSC $10-\mathrm{a}$ & NRRL 22135 & - & - & - & - & - & - & + & $\ldots$ \\
\hline FSSC 10-b & NRRL 22098 & - & - & - & - & - & - & + & $\cdots$ \\
\hline FSSC 11-1 & KOD 313 & - & - & - & - & - & - & + & $\ldots$ \\
\hline FSSC 11-o & KOD 320 & - & - & - & - & - & - & + & $\ldots$ \\
\hline FSSC 13-g & KOD 398 & - & - & - & - & - & - & + & $\cdots$ \\
\hline FSSC $13-\mathrm{k}$ & KOD 267 & - & - & - & - & - & - & + & $\ldots$ \\
\hline FSSC 14-a & KOD 450 & - & - & - & - & - & - & + & $\ldots$ \\
\hline FSSC 14-b & KOD 452 & - & - & - & - & - & - & + & $\ldots$ \\
\hline FSSC 18-f & KOD 288 & - & - & - & - & - & - & + & $\ldots$ \\
\hline FSSC 18-m & KOD 312 & - & - & - & - & - & - & + & $\ldots$ \\
\hline FSSC 25-f & KOD 384 & - & - & - & - & - & - & + & $\cdots$ \\
\hline FSSC $25-\mathrm{k}$ & KOD 389 & - & - & - & - & - & - & + & $\ldots$ \\
\hline FSSC $29-d$ & KOD 411 & - & - & - & - & - & - & + & $\ldots$ \\
\hline FSSC 29-e & KOD 407 & - & - & - & - & - & - & + & $\ldots$ \\
\hline
\end{tabular}

a An informal ad hoc nomenclature was developed to distinguish the 12 fusaria within the ambrosia Fusarium clade (AFC) (i.e., AF followed by 1 to 12 ). FSSC $=$ Fusarium solani species complex.

b Strain designations are as follows: NRRL = ARS Culture Collection, Peoria, IL and KOD = lab collection of Kerry O'Donnell.

c AFC-specific targets.

${ }^{\mathrm{d}}$ Genome was sequenced in the current study.

${ }^{\mathrm{e}}$ DNA was extracted directly from beetle heads. Ei = Euwallacea interjectus, $\mathrm{Ev}=$ E. validus, and $\mathrm{F}=$ female beetles. Number following $\mathrm{F}$ indicates number of heads included in single DNA extraction. 
optimize extraction and amplification, especially at the single-beetle level. This is particularly important given that fungal communities within mycangia are diverse (Kostovcik et al. 2015) and dynamic (Freeman et al. 2016), changing as adult females mature and prepare to emerge from their natal galleries. Results of multiplex PCR using mixed templates confirmed successful coamplification for a majority of combinations at or above $25 \mathrm{ng} / \mu \mathrm{l}$ and several at $1 \mathrm{ng} / \mu \mathrm{l}$, especially for AF-2/AF-12 mixed templates. Such coamplification is important when testing interactions (symbiont cocultivation or swapping) among Euwallacea ambrosia beetles in areas where their invaded ranges already overlap or where overlap is imminent. The latter includes the southeastern United States and California, where two or more species of exotic Euwallacea beetles might colonize the same woody host (Eskalen et al. 2013; O'Donnell et al. 2015). Given the fact that Euwallacea sp. \#1 farming F. euwallaceae, the AF-2-specific PCR assay should prove useful in tracking its spread into new areas. The AF-2/AF-12 multiplex will likely prove most useful in that Euwallacea spp. 1 and 5, farming AF-2 and AF-12, respectively, are present in southern California and pose a potential threat to avocado production in the commercial groves there and in Mexico.

Globally, several Fusarium canker diseases have inflicted widespread mortality and economic loss on both native and cultivated crop and timber trees. Canker pathogens in the $F$. torreyae species complex currently threaten endemic Florida torreya (Torreya taxifolia Arn.) and cultivated prickly ash (Zanthoxylum bungeanum Maxim.) in China (Aoki et al. 2013; Smith et al. 2011; Zhou et al. 2016). Certain members of the FSSC have also been implicated as causal agents in the disease complex thousand cankers disease of walnut (Juglans spp.) in western United States and Europe (Montecchio et al. 2015; Tisserat et al. 2009). F. circinatum, a member of the $F$. fujikuroi species complex (Nirenberg and O'Donnell 1998) and causal agent of pitch canker,

Table 3. Results of the polymerase chain reaction simplexes targeting six ambrosia Fusarium clade (AFC) species

\begin{tabular}{|c|c|c|c|c|c|c|c|c|c|c|}
\hline \multirow[b]{2}{*}{ Sample } & \multirow[b]{2}{*}{ AFC species } & \multirow[b]{2}{*}{$\mathrm{IC}(\mathrm{ng} / \mu \mathrm{l})^{\mathrm{b}}$} & \multicolumn{8}{|c|}{ Approximate concentrations $^{\mathbf{a}}$} \\
\hline & & & $100 \mathrm{ng} / \mu \mathrm{l}$ & $50 \mathrm{ng} / \mu \mathrm{l}$ & $25 \mathrm{ng} / \mu \mathrm{l}$ & $10 \mathrm{ng} / \mu \mathrm{l}$ & $1 \mathrm{ng} / \mu \mathrm{l}$ & $100 \mathrm{pg} / \mu \mathrm{l}$ & $10 \mathrm{pg} / \mu \mathrm{l}$ & $1 \mathrm{pg} / \mu \mathrm{l}$ \\
\hline 54727 & $\mathrm{AF}-2$ & 47 & $\mathrm{n} / \mathrm{a}$ & + & + & + & + & - & - & - \\
\hline 62626 & AF-2 & 115 & + & + & + & + & + & - & - & - \\
\hline MB202 & $\mathrm{AF}-3$ & 94 & + & + & + & + & + & - & - & - \\
\hline 62605 & $\mathrm{AF}-3^{\mathrm{c}}$ & 104 & + & + & + & + & + & - & - & - \\
\hline MB14 & $\mathrm{AF}-4$ & 112 & + & + & + & + & + & + & + & + \\
\hline MB42 & AF-4 & 99 & + & + & + & + & + & - & + & + \\
\hline 62591 & AF-6 & 103 & + & + & + & + & + & + & - & + \\
\hline 62590 & AF-6 & 99 & + & + & + & + & + & + & - & - \\
\hline 62585 & AF-8 & 84 & + & + & + & + & + & + & + & + \\
\hline 62584 & AF-8 & 117 & + & + & + & + & + & + & + & - \\
\hline 62945 & AF12 & 75 & + & + & + & + & + & - & - & - \\
\hline 62946 & AF12 & 98 & + & + & + & + & + & - & - & - \\
\hline
\end{tabular}

a Initial DNA template was approximately $50 \mathrm{ng} / \mu \mathrm{l}$; therefore, no PCR was conducted for the approximately $100 \mathrm{ng} / \mu \mathrm{l}$ concentration (n/a).

${ }^{\mathrm{b}}$ Initial concentration.

${ }^{\mathrm{c}}$ Multiparent interspecific hybrid.

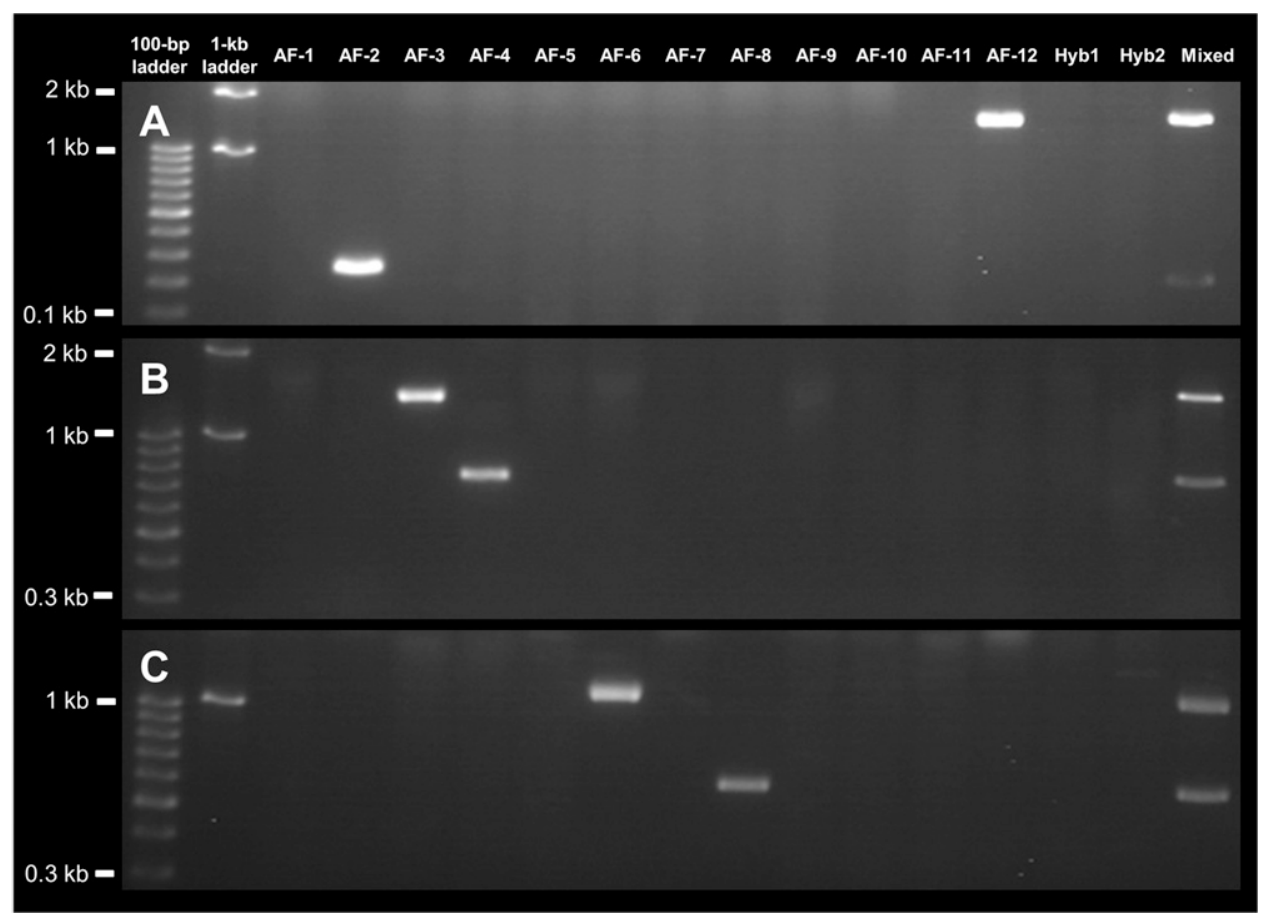

Fig. 2. Gel electrophoresis of amplicons generated using three different species-specific multiplexes. A, AF-2/AF-12; B, AF-3/AF-4; C, AF-6/AF-8. Strains used in multiplexes are as follows: AF-1 = NRRL 20438, AF-2 = NRRL 54727, AF-3 = NRRL 62629, AF-4 = NRRL 62579, AF-5 = NRRL 22231, AF-6 = NRRL 62590, AF-7 = NRRL 62610, AF-8 = NRRL 62585, AF-9 = NRRL 22643, AF-10 = NRRL 62941, AF-11 = NRRL 62944, AF-12 = NRRL 62945, Hyb1 = NRRL 46583, and Hyb2 = NRRL 22345. Mixed templates consisted of DNA from the same strains listed. 
continues to affect numerous pine species throughout the northern and southern hemispheres (Wingfield et al. 2008).

The spread of Fusarium tree diseases, including pitch canker, which has been confirmed on dozens of native and cultivated pine species and associated with numerous insect vectors, is of great concern to countries such as Australia and New Zealand, where extensive plantations of highly susceptible Pinus radiata are grown (Dick 1998). In response to these threats, several molecular methods for the rapid and sensitive detection of $F$. circinatum from bark beetles (Fourrier et al. 2015), seed (Dreaden et al. 2012), and spore traps (Schweigkofler et al. 2004) were developed. These molecular tools have likely mitigated additional spread of pitch canker, especially in infected nursery stock, which historically relied on less accurate and less sensitive culture-based screening methods for detection of pathogens, which were prone to false negatives (Dreaden et al. 2012).

Fusarium canker and associated dieback, caused by members of the monophyletic AFC and their Euwallacea vectors, also affects numerous tree species within the United States, as well as cultivated crop and timber species planted worldwide. Several species, including boxelder, California sycamore, and native willow species, are
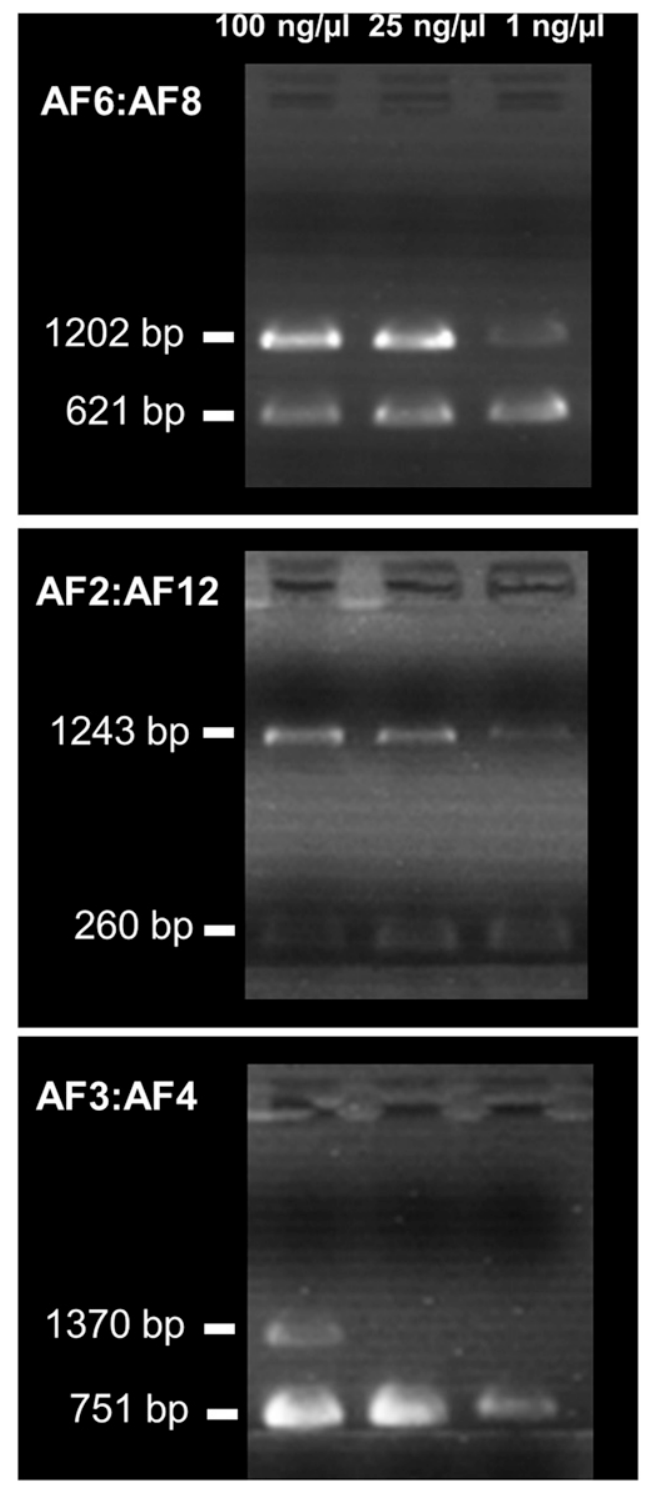

Fig. 3. Gel electrophoresis for representative mixed-template amplicons generated using three different species-specific multiplexes across three different genomic DNA (gDNA) concentrations. Concentrations included 100, 25, and $1 \mathrm{ng} / \mu \mathrm{l}$. Mixed templates consisted of $1 \mu \mathrm{l}$ of gDNA from each of two strains. Mixed templates were as follows: AF-6/AF-8 = NRRL 62591/NRRL 62584, AF-2/AF-12 = NRRL 62626/NRRL 62945, and AF-3/AF-4 = NRRL 62605/MB14. currently at risk for widespread beetle infestations and associated mortality, especially in California. Euwallacea spp. within the E. fornicatus species complex have been confirmed attacking native vegetation in many new areas throughout San Diego, Los Angeles, Orange, and Riverside Counties (Boland 2016; Lynch et al. 2016). Avocado has also been affected in California, Israel, and partially in Florida, although the severity of damage is highly variable regionally and temporally (Mendel et al. 2012; Freeman et al. 2013). Future introductions of exotic beetles are anticipated and the ranges of established polyphagous Euwallacea spp. are expected to expand. As beetle populations grow and disseminate, additional native plant species will likely be affected, including some that may serve as suitable reproductive hosts for the beetles.

The availability of inexpensive whole-genome sequencing coupled with user-friendly sequence analysis software greatly facilitated identification of species-specific primer binding sites for distinguishing the six AFC species currently known within the United States. Whole-genome sequences of closely related fungal species has provided new insight into many other economically important fungal pathogens (Jones et al. 2014; Schmidt et al. 2016), including other fusaria (Maphosa et al. 2016). This diagnostic tool can easily be expanded in the event that other AFC-Euwallacea mutualists are introduced into the United States. Individual (simplex) diagnostic primer pairs can economize screening in regions where only a single AFC species is present, such as AF-2 in Israel. PCR assays provide several obvious advantages over multilocus sequencing for identifying AFC species, such as increased speed and volume of samples that can be screened as well as reduced cost. In summary, the PCR assays to discriminate Fusarium symbionts of exotic Euwallacea ambrosia beetles provide a foundation for rapid and widespread molecular surveillance focused on tracking changes in AFC species' host range and geographic distribution over time.

\section{Acknowledgments}

D. P. G. Short and M. T. Kasson were supported by funds appropriated under the Hatch Project WVA00662. A. I. Cognato was funded by United States Department of Agriculture (USDA) Forest Service Early Detection Rapid Response program (11-DG-11420004-257). J. Hulcr and C. C. Bateman were partially funded by the USDA Forest Service Coop agreement 12-CA-11420004-042, USDA Farm Bill agreement 12-8130-0377-CA, and the National Science Foundation DEB 1256968

\section{Literature Cited}

Aoki, T., Smith, J. A., Mount, L. L., Geiser, D. M., and O’Donnell, K. 2013. Fusarium torreyae sp. nov., a pathogen causing canker disease of Florida torreya (Torreya taxifolia), a critically endangered conifer restricted to northern Florida and southwestern Georgia. Mycologia 105:312-319.

Atkinson, T. H. 2016. Bark and ambrosia beetles. Online publication. http:// barkbeetles.info/

Balestra, G. M., Taratufolo, M. C., Vinatzer, B. A., and Mazzaglia, A. 2013. A multiplex PCR assay for detection of Pseudomonas syringae pv. actinidiae and differentiation of populations with different geographic origin. Plant Dis. 97:472-478.

Boland, J. M. 2016. The impact of an invasive ambrosia beetle on the riparian habitats of the Tijuana River Valley, California. PeerJ 4:e2141.

Borodovsky, M., and Lomsadze, A. 2011. Eukaryotic gene prediction using GeneMark.hmm-E and GeneMark-ES. Unit 4.6.1-4.6.10 in: Current Protocols in Bioinformatics. Online publication. Wiley Online Library. 10.1002/0471250953.bi0406s35

Campbell, M. S., Holt, C., Moore, B., and Yandell, M. 2014. Genome annotation and curation using MAKER and MAKER-P. Unit 4.11.1-4.11.39 in: Current Protocols in Bioinformatics. Online publication. Wiley Online Library.

Cognato, A. I., Hoebeke, E. R., Kajimura, H., and Smith, S. M. 2015. History of the exotic ambrosia beetles Euwallacea interjectus and Euwallacea validus (Coleoptera: Curculionidae: Xyleborini) in the United States. J. Econ. Entomol. 108:1129-1135.

Dick, M. A. 1998. Pine pitch canker-The threat to New Zealand. N. Z. For. 42:30-34

Dreaden, T. J., Davis, J. M., Harmon, C. L., Ploetz, R. C., Palmateer, A. J., Soltis, P. S., and Smith, J. A. 2014. Development of multilocus PCR assays for Raffaelea lauricola, causal agent of laurel wilt disease. Plant Dis. 98:379-383.

Dreaden, T. J., Smith, J. A., Barnard, E. L., and Blakeslee, G. 2012. Development and evaluation of a real-time PCR seed lot screening method for Fusarium circinatum, causal agent of pitch canker disease. For. Pathol. 42:405-411.

Elmore, M. H., McGary, K. L., Wisecaver, J. H., Slot, J. C., Geiser, D. M., Sink, S., O'Donnell, K., and Rokas, A. 2015. Clustering of two genes putatively involved in cyanate detoxification evolved recently and independently in multiple fungal lineages. Genome Biol. Evol. 7:789-800. 
Eskalen, A., Stouthamer, R., Lynch, S. C., Rugman-Jones, P. F., Twizeyimana, M., Gonzalez, A., and Thibault, T. 2013. Host range of Fusarium dieback and its ambrosia beetle (Coleoptera: Scolytinae) vector in southern California. Plant Dis. 97:938-951.

Fourrier, C., Antoine, S., Piou, D., and Loos, R. 2015. Rapid detection of Fusarium circinatum propagules on trapped pine beetles. For. Pathol. 45:324-330.

Fraedrich, S. W., Harrington, T. C., Rabaglia, R. J., Ulyshen, M. D., Mayfield, A. E., III, Hanula, J. L., Eickwort, J. M., and Miller, D. R. 2008. A fungal symbiont of the redbay ambrosia beetle causes a lethal wilt in redbay and other Lauraceae in the southeastern United States. Plant Dis. 92:215-224.

Freeman, S., Sharon, M., Dori-Bachash, M., Maymon, M., Belausov, E., Maoz, Y., Margalit, O., Protasov, A., and Mendel, Z. 2016. Symbiotic association of three fungal species throughout the life cycle of the ambrosia beetle Euwallacea nr. fornicatus. Symbiosis 68:115-128.

Freeman, S., Sharon, M., Maymon, M., Mendel, Z., Protasov, A., Aoki, T., Eskalen, A., and O'Donnell, K. 2013. Fusarium euwallaceae sp. nov. - a symbiotic fungus of Euwallacea sp., an invasive ambrosia beetle in Israel and California. Mycologia 105:1595-1606.

Fu, L., Niu, B., Zhu, Z., Wu, S., and Li, W. 2012. CD-HIT: Accelerated for clustering the next-generation sequencing data. Bioinformatics 28:3150-3152.

Gadd, C. H., and Loos, C. A. 1947. The ambrosia fungus of Xyleborus fornicatus Eich. Trans. Br. Mycol. Soc. 30:13-18, plus plate I.

Grabherr, M. G., Haas, B. J., Yassour, M., Levin, J. Z., Thompson, D. A., Adiconis, X., Fan, L., Raychowdhury, R., Zeng, Q., Chen, Z., Mauceli, E., Hacohen, N., Gnirke, A., Rhind, N., di Palma, F., Birren, B. W., Nusbaum, C., Lindblad-Toh, K., Friedman, N., and Regev, A. 2011. Full-length transcriptome assembly from RNA-Seq data without a reference genome. Nat. Biotechnol. 29:644-652.

Haas, B. J., Papanicolaou, A., Yassour, M., Grabherr, M., Blood, P. D., Couger, M. B., Eccles, D., Li, B., Lieber, M., MacManes, M. D., Ott, M., Orvis, J., Pochet, N., Strozzi, F., Weeks, N., Westerman, R., William, T., Dewey, C. N., Henschel, R., LeDuc, R. D., Friedman, N., and Regev, A. 2013. De novo transcript sequence reconstruction from RNA-seq using the Trinity platform for reference generation and analysis. Nat. Protoc. 8:1494-1512.

Inderbitzin, P., Davis, R. M., Bostock, R. M., and Subbarao, K. V. 2013. Identification and differentiation of Verticillium species and V. longisporum lineages by simplex and multiplex PCR assays. PLoS One 8:e65990.

Jones, L., Riaz, S., Morales-Cruz, A., Amrine, K. C., McGuire, B., Gubler, W. D., Walker, M. A., and Cantu, D. 2014. Adaptive genomic structural variation in the grape powdery mildew pathogen, Erysiphe necator. BMC Genomics 15:1081.

Kasson, M. T., O’Donnell, K., Rooney, A. P., Sink, S., Ploetz, R. C., Ploetz, J. N., Konkol, J. L., Carrillo, D., Freeman, S., Mendel, Z., Smith, J. A., Black, A. W., Hulcr, J., Bateman, C., Stefkova, K., Campbell, P. R., Geering, A. D. W., Dann, E. K., Eskalen, A., Mohotti, K., Short, D. P. G., Aoki, T., Fenstermacher, K. A., Davis, D. D., and Geiser, D. M. 2013. An inordinate fondness for Fusarium: Phylogenetic diversity of fusaria cultivated by ambrosia beetles in the genus Euwallacea on avocado and other plant hosts. Fungal Genet. Biol. 56:147-157.

Korf, I. 2004. Gene finding in novel genomes. BMC Bioinf. 5:59.

Kostovcik, M., Bateman, C. C., Kolarik, M., Stelinski, L. L., Jordal, B. H., and Hulcr, J. 2015. The ambrosia symbiosis is specific in some species and promiscuous in others: Evidence from community pyrosequencing. ISME J. 9:126-138

Lynch, S., Eskalen, A., and Gilbert, G. S. 2016. New pest-disease complex threatens California forests. Cal-IPC News 24:12-13.

Maphosa, M. N., Steenkamp, E. T., and Wingfield, B. D. 2016. Genome-based selection and characterization of Fusarium circinatum-specific sequences. G3 Genes Genomes Genet. 6:631-639.

Mendel, Z., Protasov, A., Sharon, M., Zveibil, A., Yehuda, S. B., O’Donnell, K., Rabaglia, R., Wysoki, M., and Freeman, S. 2012. An Asian ambrosia beetle Euwallacea fornicatus and its novel symbiotic fungus Fusarium sp. pose a serious threat to the Israeli avocado industry. Phytoparasitica 40:235-238.

Montecchio, L., Faccoli, M., Short, D. P. G., Fanchin, G., Geiser, D. M., and Kasson, M. T. 2015. First Report of Fusarium solani phylogenetic species 25 associated with early stages of thousand cankers disease on Juglans nigra and Juglans regia in Italy. Plant Dis. 99:1183.

Nirenberg, H. I., and O'Donnell, K. 1998. New Fusarium species and combinations within the Gibberella fujikuroi species complex. Mycologia 90: 434-458.

O'Donnell, K., Cigelnik, E., and Nirenberg, H. 1998. Molecular systematics and phylogeography of the Gibberella fujikuroi species complex. Mycologia 90: 465-493.

O’Donnell, K., Sink, S., Libeskind-Hadas, R., Hulcr, J., Kasson, M. T., Ploetz, R. C., Konkol, J. L., Ploetz, J. N., Carrillo, D., Campbell, A., and Duncan, R. E. 2015.
Discordant phylogenies suggest repeated host shifts in the Fusarium-Euwallacea ambrosia beetle mutualism. Fungal Genet. Biol. 82:277-290.

O’Donnell, K., Sutton, D. A., Fothergill, A., McCarthy, D., Rinaldi, M. G., Brandt, M. E., Zhang, N., and Geiser, D. M. 2008. Molecular phylogenetic diversity, multilocus haplotype nomenclature, and in vitro antifungal resistance within the Fusarium solani species complex. J. Clin. Microbiol. 46:2477-2490.

Park, J. H., and Juzwik, J. 2012. Fusarium canker of bitternut hickory caused by Fusarium solani in the north-central and northeastern United States. Plant Dis. 96:455.

Ploetz, R. C., Hulcr, J., Wingfield, M. J., and De Beer, Z. W. 2013. Destructive tree diseases associated with ambrosia and bark beetles: Black swan events in tree pathology? Plant Dis. 97:856-872

Rigotti, S., Gindro, K., Richter, H., and Viret, O. 2002. Characterization of molecular markers for specific and sensitive detection of Botrytis cinerea Pers.: Fr. in strawberry (Fragaria $\times$ ananassa Duch.) using PCR. FEMS Microbiol. Lett. 209:169-174.

Schmidt, S. M., Lukasiewicz, J., Farrer, R., Dam, P., Bertoldo, C., and Rep, M 2016. Comparative genomics of Fusarium oxysporum f. sp. melonis reveals the secreted protein recognized by the Fom-2 resistance gene in melon. New Phytol. 209:307-318.

Schweigkofler, W., O'Donnell, K., and Garbelotto, M. 2004. Detection and quantification of airborne conidia of Fusarium circinatum, the causal agent of pine pitch canker, from two California sites by using a real-time PCR approach combined with a simple spore trapping method. Appl. Environ. Microbiol. 70:3512-3520.

Short, D. P. G., Double, M., Nuss, D. L., Stauder, C. M., MacDonald, W., and Kasson, M. T. 2015. Multilocus PCR assays elucidate vegetative incompatibility gene profiles of Cryphonectria parasitica in the United States. Appl. Environ. Microbiol. 81:5736-5742

Short, D. P. G., O'Donnell, K., Thrane, U., Nielsen, K. F., Zhang, N., Juba, J. H., and Geiser, D. M. 2013. Phylogenetic relationships among members of the Fusarium solani species complex in human infections and the descriptions of $F$. keratoplasticum sp. nov. and $F$. petroliphilum stat. nov. Fungal Genet. Biol. 53:59-70

Slater, G. S., and Birney, E. 2005. Automated generation of heuristics for biological sequence comparison. BMC Bioinf. 6:31.

Smith, J. A., O’Donnell, K., Mount, L. L., Shin, K., Pacock, K., Trulock, A. Spector, T., Cruse-Sanders, J., and Determann, R. 2011. A novel Fusarium species causes a canker disease of the critically endangered conifer, Torreya taxifolia. Plant Dis. 95:633-639.

Stanke, M., Schoffmann, O., Morgenstern, B., and Waack, S. 2006. Gene prediction in eukaryotes with a generalized hidden Markov model that uses hints from external sources. BMC Bioinf. 7:62.

Storer, C. G., Breinholt, J. W., and Hulcr, J. 2015. Wallacellus is Euwallacea: Molecular phylogenetics settles generic relationships (Coleoptera: Curculionidae: Scolytinae: Xyleborini). Zootaxa 3974:391.

Taylor, J. W., Jacobson, D. J., Kroken, S., Kasuga, T., Geiser, D. M., Hibbett D. S., and Fisher, M. C. 2000. Phylogenetic species recognition and species concepts in fungi. Fungal Genet. Biol. 31:21-32.

Ter-Hovhannisyan, V., Lomsadze, A., Chernoff, Y. O., and Borodovsky, M. 2008 Gene prediction in novel fungal genomes using an ab initio algorithm with unsupervised training. Genome Res. 18:1979-1990.

Tisserat, N. 1987. Stem canker of black-walnut caused by Fusarium solani in Kansas. Plant Dis. 71:557.

Tisserat, N., Cranshaw, W., Leatherman, D., Utley, C., and Alexander, K. 2009 Black walnut mortality in Colorado caused by the walnut twig beetle and thousand cankers disease. Online publication. Plant Health Prog. doi:10.1094/ PHP-2009-0811-01-RS

Wingfield, M. J., Hammerbacher, A., Ganley, R. J., Steenkamp, E. T., Gordon, T. R., Wingfield, B. D., and Coutinho, T. A. 2008. Pitch canker caused by Fusarium circinatum-A growing threat to pine plantations and forests worldwide. Australas. Plant Pathol. 37:319-334.

Wood, S. L. 1982. The bark and ambrosia beetles of North and Central America (Coleoptera: Scolytidae), a taxonomic monograph. Great Basin Naturalist Memoirs No. 6. Brigham Young University, Provo, UT.

Zhang, N., O'Donnell, K., Sutton, D. A., Nalim, F. A., Summerbell, R. C., Padhye, A. A., and Geiser, D. M. 2006. Members of the Fusarium solani species complex that cause infections in both humans and plants are common in the environment. J. Clin. Microbiol. 44:2186-2190.

Zhou, X., O’Donnell, K., Aoki, T., Smith, J., Kasson, M. T., and Cao, Z. M. 2016 Two novel Fusarium species that cause canker disease of prickly ash (Zanthoxylum bungeanum) in northern China form a novel clade with Fusarium torreyae. Mycologia 108:668-681. 